\title{
Real-time PCR analysis of leptin and leptin receptor expression in the rat prostate, and effects of leptin on prostatic acid phosphatase release
}

\author{
WITOLD MALENDOWICZ ${ }^{1}$, MARCIN RUCINSKI ${ }^{2}$, ANNA S. BELLONI ${ }^{3}$, \\ AGNIESZKA ZIOLKOWSKA ${ }^{2}$, GASTONE G. NUSSDORFER ${ }^{3}$ and ZBIGNIEW KWIAS ${ }^{1}$
}

\begin{abstract}
Departments of ${ }^{1}$ Urology and ${ }^{2}$ Histology and Embryology, Poznan University of Medical Sciences, PL-60781 Poznan, Poland; ${ }^{3}$ Department of Human Anatomy and Physiology, Section of Anatomy, University of Padua, I-35121 Padua, Italy
\end{abstract}

Received June 20, 2006; Accepted August 22, 2006

\begin{abstract}
We have recently demonstrated the expression of leptin and leptin receptor (Ob-R) isoforms $\mathrm{a}, \mathrm{b}, \mathrm{c}$, e and $\mathrm{f}$ in the rat seminal vesicles and prostate. The aim of the present study was to provide a semiquantitative real-time PCR estimation of leptin/Ob-R isoform mRNA expression in the seminal vesicles and individual components of rat prostate, and to ascertain the in vitro effects of leptin on prostate acid phosphatase release. The highest expression of the leptin and $\mathrm{Ob}-\mathrm{R}$ genes was in the seminal vesicles and lateral prostate lobe, respectively. Of the various isoforms, $\mathrm{Ob}-\mathrm{Rb}$ displayed the highest and Ob-Re the lowest expression. Leptin $\left(10^{-8}\right.$ and $10^{-6} \mathrm{M}$ ) enhanced acid phosphate release from seminal vesicles, and $\left(10^{-6} \mathrm{M}\right)$ decreased it from the coagulating lobe. Taken together, our findings support the contention that leptin may be involved in the autocrine-paracrine functional regulation of rat seminal vesicles and prostate. The physiological relevance of the marked heterogeneity of the different prostate lobes in both their leptin/Ob-R expression and functional response to leptin remains to be addressed.
\end{abstract}

\section{Introduction}

Despite evidence strongly suggesting the involvement of leptin in the regulation of growth and function of the prostate and prostate tumors (1-7), investigations on the expression of leptin and its receptor isoforms in the human normal and tumorous prostate are very scarce (4,8-10). Using reverse transcription (RT)-polymerase chain reaction (PCR), Western blotting and immunocytochemistry, we have recently demonstrated the expression of leptin and leptin receptor $(\mathrm{Ob}-\mathrm{R})$ isoforms

Correspondence to: Professor G.G. Nussdorfer, Department of Human Anatomy and Physiology, Section of Anatomy, Via Gabelli 65, I-35121 Padua, Italy

E-mail: gastone.nusdorfer@unipd.it

Key words: leptin, Ob-R, acid phosphatase release, seminal vesicles, prostate, rat (a,b,c,e and f) in the seminal vesicles and coagulating, dorsal, lateral and ventral lobes of the rat prostate (11).

The structural and functional heterogeneity of the individual lobes of the rat prostate is well known (12), especially as far as the epithelial-cell responses to androgens and other hormones are concerned (13-16). There are also clear-cut differences in the level of expression of non-gastric $\mathrm{H}^{+} / \mathrm{K}^{+}$-ATPase- $\alpha$ and endothelin receptor density $(17,18)$, and in the secretion of prostate secretory protein (PSP94) and protease inhibitors $(19,20)$. Moreover, angiographic studies demonstrated that the prostate ventral lobe is better irrigated than the dorsal one (21).

Based on these considerations, it seems worthwhile to investigate by semiquantitative real-time PCR the mRNA expression of leptin and $\mathrm{Ob}-\mathrm{R}$ isoforms in the rat seminal vesicles and individual prostate lobes, as well as to examine the effects of leptin on the specialized function of their epithelial cells (i.e. acid phosphatase release).

\section{Materials and methods}

Animals and reagents. Adult male rats (200-250 g body weight), bred in our laboratory facilities, were kept under a 14:10-h light:dark cycle (illumination onset at 6:00 a.m.) at $23^{\circ} \mathrm{C}$, and maintained on a standard diet with free access to tap water. Rats were decapitated, and their prostates with seminal vesicles were promptly removed. The study protocol was approved by the local ethics committee for biomedical studies. Recombinant murine leptin(1-147) was purchased from PreproTech EC (London, UK), and Iscador Qu (mistletoe preparation) from Weleda Co. (Schwabisch Gmund, Germany). RPMI-1640 medium, and all other chemicals and reagents were provided by Sigma-Aldrich Corp. (St. Louis, MO).

Real time-PCR. Total RNA was extracted from seminal vesicles and prostate coagulating, dorsal, lateral and ventral lobes $(22,23)$, and reverse transcribed, as previously detailed $(24,25)$. Real-time PCR was carried out in a Roche LightCycler 2.0 with software version $4.0(26,27)$, using the following program: denaturation step $\left(95^{\circ} \mathrm{C}\right.$ for $\left.10 \mathrm{~min}\right)$, and 45 cycles of three step amplification (denaturation, $95^{\circ} \mathrm{C}$ for $10 \mathrm{sec}$; annealing, $58^{\circ} \mathrm{C}$ for $5 \mathrm{sec}$; and extension, $72^{\circ} \mathrm{C}$ for $10 \mathrm{sec}$ ). 


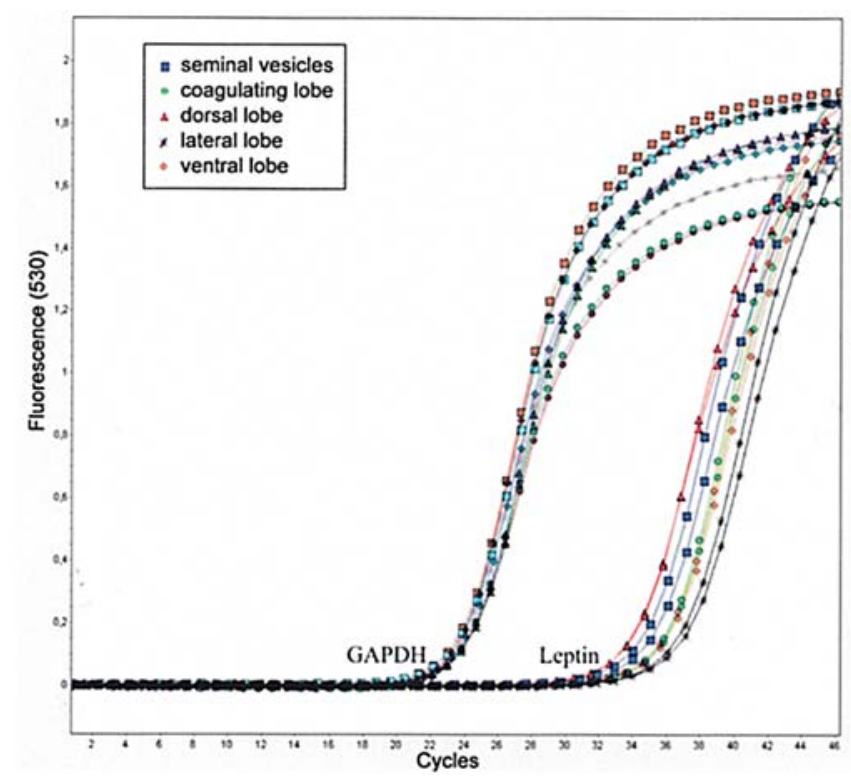

Figure 1. Amplification curves of leptin cDNA obtained from mRNA isolated from seminal vesicles and prostate lobes of an exemplary adult rat.

Subsequently, melting curve $\left(60-90^{\circ} \mathrm{C}\right.$ with a heating rate of $0.1^{\circ} \mathrm{C} / \mathrm{sec}$ ) was performed to check the specificity of amplification and the presence of byproducts. All samples were amplified in duplicate, and the glyceraldehyde-3-phosphatase dehydrogenase (GAPDH) gene was used as a reference to normalize data. The primer sequences were those reported previously (11).

Acid phosphatase release. Seminal vesicles and prostate were squeezed to remove their content, and carefully dissected and sliced. Fragments (60-100 mg) of seminal vesicles and prostate ventral and coagulating lobes were incubated in $1 \mathrm{ml}$ RPMI1640 medium for $10 \mathrm{~h}$ at $37^{\circ} \mathrm{C}$ in an atmosphere of $5 \% \mathrm{CO}_{2}$ $95 \%$ air and $100 \%$ humidity. The medium was discarded, and new medium, containing Iscador $\mathrm{Qu}(1 \mathrm{mg} / \mathrm{ml})$ or leptin $\left(10^{-8}\right.$ and $\left.10^{-6} \mathrm{M}\right)$, was added. Fragments were incubated for $120 \mathrm{~min}$. Prostatic acid phosphatase activity in the incubation medium was measured by a commercial kit (Pointe Scientific, Canton, MI). In this assay, $\alpha$-naphtylphosphate was added to the medium, and the reaction of the released $\alpha$-naphtyl with Fast Red TR was measured at $405 \mathrm{~nm}$ wavelength in a microplate autoreader (EL-13; Bio-Tek Instruments, Winooski, VT). Data were expressed as the mean \pm SEM of 8 independent experiments, and their statistical comparison was made by the unpaired Student's t-test.

\section{Results}

Real time-PCR confirmed (11) the expression of the leptin gene in both rat seminal vesicles and prostate lobes (Fig. 1). Semiquantitative estimation showed the highest expression of leptin mRNA in the seminal vesicles and dorsal lobe, and the lowest expression in the coagulating, lateral and ventral lobes (Fig. 2).

The level of expression of $\mathrm{Ob}-\mathrm{R}$ isoforms in the various tissues examined was as follows: i) Ob-Ra, ventral lobe $>$ lateral lobe $>>$ seminal vesicles and coagulating and dosal

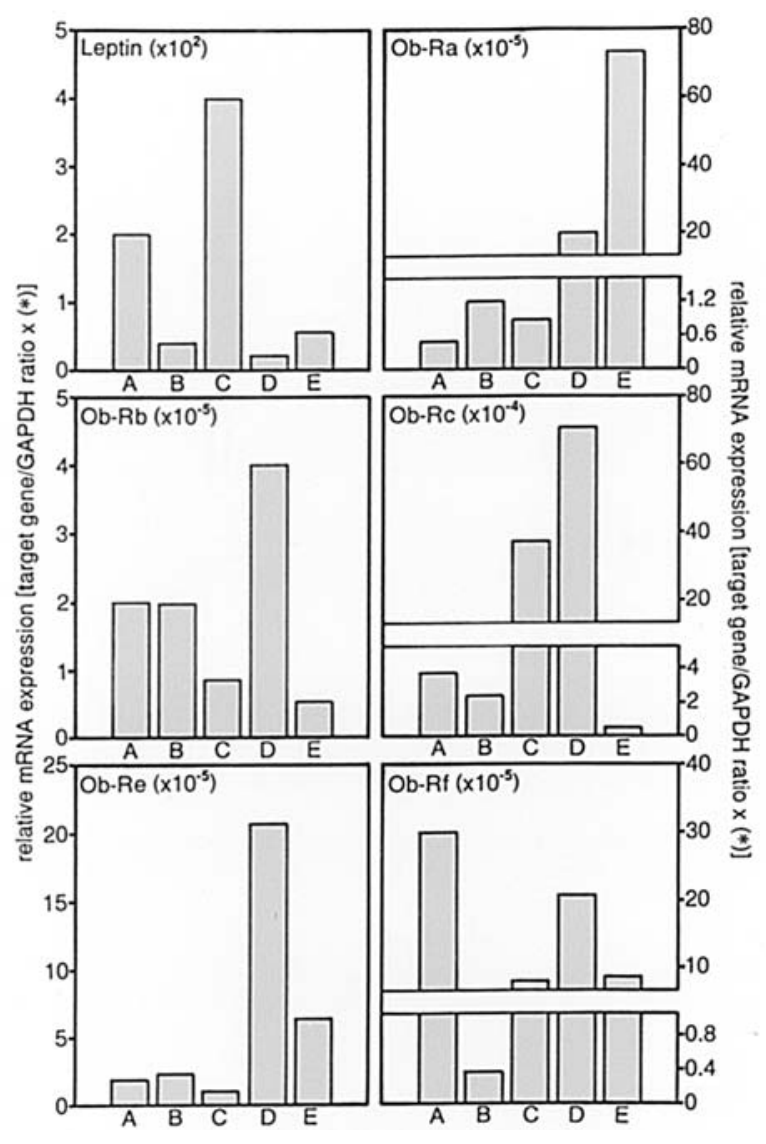

Figure 2. Real-time PCR semiquantitative analysis of leptin and Ob-R gene expression in the seminal vesicles (A), and coagulating (B), dorsal (C), lateral (D) and ventral lobes (E) of the prostates of adult rats. Bars are means of two independent estimations.

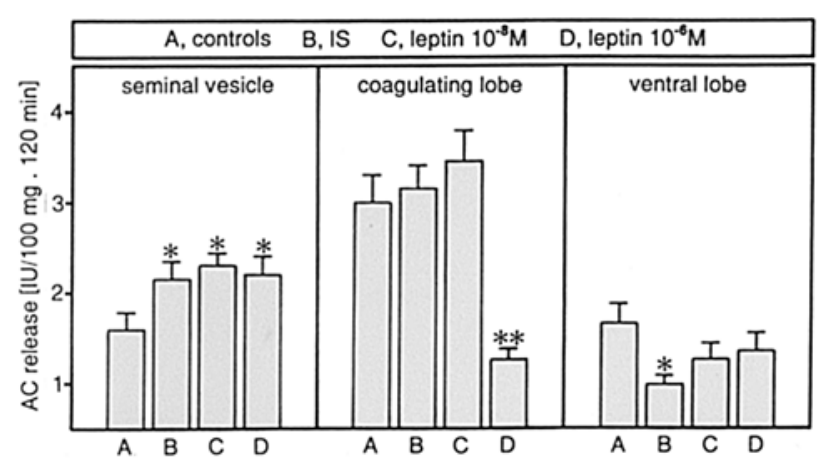

Figure 3. Effects of Iscador Qu (IS) and leptin on acid phosphatase (AC) release from seminal vesicles and prostate lobes of adult rats. Bars are means \pm SEM of 8 independent experiments. ${ }^{*} \mathrm{P}<0.05$ and ${ }^{* *} \mathrm{P}<0.01$ from the respective control group.

lobes; ii) Ob-Rb, lateral lobe > seminal vesicles and coagulating lobe $>$ dorsal and ventral lobes; iii) Ob-Rc, lateral lobe $>$ dorsal lobe $>>$ seminal vesicles and coagulating lobes $>$ ventral lobe; iv) Ob-Re, lateral lobe $>$ ventral lobe $>$ seminal vesicles and coagulating and dorsal lobes; and v) Ob-Rf, seminal vesicles and lateral lobe $>$ dorsal and ventral lobes $>>$ coagulating lobe (Fig. 2).

Iscador Qu lowered acid phosphatase release from the prostate ventral lobe, but not from the coagulating lobe, and 
raised that from seminal vesicles. Leptin did not affect acid phosphatase release from the ventral lobe and enhanced that from seminal vesicles. At the higher concentration $\left(10^{-6} \mathrm{M}\right)$, leptin decreased acid phosphatase release from the coagulating lobe (Fig. 3).

\section{Discussion}

Our present findings confirm and expand our previous observations (11), and show a notable heterogeneity among seminal vesicles and various prostate lobes as far as the level of leptin/Ob-R expression and effects of leptin on the specialized function of their epithelial cells are concerned.

The highest relative expression of the leptin gene was found in the seminal vesicles and dorsal prostatic lobe, while that of Ob-R was observed in the lateral lobe. It is well known that only $\mathrm{Ob}-\mathrm{Rb}$, i.e. the long isoform of $\mathrm{Ob}-\mathrm{R}$ which possesses an intracytoplasmic domain of 302 amino acids, contains all motifs (among which Box 1 and Box 2) necessary for the complete activation of JAK-STAT and MAPK cascades, while $\mathrm{Ob}-\mathrm{Re}$ does not possess a transmembrane domain and only circulates as a soluble receptor. Other Ob-R isoforms (Ob-Ra, $\mathrm{Ob}-\mathrm{Rc}$ and $\mathrm{Ob}-\mathrm{Rf})$, due to their truncated intracytoplasmic domain, are able to activate only parts of the leptin signaling pathways (28-36). On these grounds, it appears of great interest that our real-time PCR assay showed that, of the Ob-R isoforms studied in seminal vesicles and prostate, $\mathrm{Ob}-\mathrm{Rb}$ displays the highest and $\mathrm{Ob}-\mathrm{Re}$ the lowest expression.

The effects of leptin on acid phosphatase release from rat seminal vesicles and prostate have been examined and compared to those of Iscador Qu. Mistletoe (Viscum album L) extract Iscador $\mathrm{Qu}$ is commonly used in experiments on the prostate (37), because it contains high concentrations of lectins, which are known to bind and release prostatic acid phosphatase $(37,38)$. Although both leptin and Iscador Qu enhance acid phosphatase release from seminal vesicles, their effects on prostate are notably different, inasmuch as the two compounds lower the enzyme release from the coagulating and the ventral lobe, respectively. Unfortunately, our findings do not allow us to correlate, even tentatively, the functional response to leptin of the various prostate lobes with their level of expression of Ob-Rs.

Despite these disappointing limitations, our study provides evidence that leptin may be involved in the autocrine-paracrine regulation of the biological activity of epithelial cells of the rat seminal vesicles and prostate. Although the possibility that locally synthesized leptin may be secreted into the lumen of the glands remains an open issue, the indentification of free leptin in human seminal plasma appears to support this contention (39). Moreover, our investigation clearly demonstrates a striking heterogeneity among the various prostate lobes in both leptin/Ob-R expression and functional response to leptin, whose physiological relevance remains to be assessed.

\section{Acknowledgements}

In partial fulfillment of the Ph.D. thesis requirement of the School of Medicine, Poznan University of Medical Sciences by W. Malendowicz.

\section{References}

1. Onuma M, Bub JD, Rummel TL and Iwamoto Y: Prostate cancer cell-adipocyte interaction: leptin mediates androgenindependent prostate cancer cell proliferation through c-Jun NH2-terminal kinase. J Biol Chem 278: 42660-42667, 2003.

2. Frankenberry KA, Somasundar P, McFadden DW and VonaDavis LC: Leptin induces cell migration and the expression of growth factors in human prostate cancer cells. Am J Surg 188: 560-565, 2004.

3. Ribeiro R, Lopez C and Medeiros R: Leptin and prostate: implications for cancer prevention. Overview of genetics and molecular interactions. Eur J Cancer Prev 13: 359-368, 2004.

4. Somasundar P, Frankenberry KA, Skinner H, Vedula G, McFadden DW, Riggs D, Jackson B, Vangilder R, Hileman SM and Vona-Davis LC: Prostate cancer cell proliferation is influenced by leptin. J Surg Res 118: 71-82, 2004.

5. Amling CL: Relationship between obesity and prostate cancer. Curr Opin Urol 15: 167-171, 2005.

6. Baillargeon J and Rose DP: Obesity, adipokines and prostate cancer. Int J Oncol 28: 737-745, 2006.

7. Bub JD, Miyazaki T and Iwamoto Y: Adiponectin as a growth inhibitor in prostate cancer cells. Biochem Biophys Res Commun 340: 1158-1166, 2006.

8. Cioffi JA, Shafer AW, Zupancic TJ, Smith-Gbur J, Mikhail A, Platika D and Snodgrass HR: Novel B219/OB receptor isoforms: possible role of leptin in hematopoiesis and reproduction. Nat Med 2: 585-589, 1996.

9. Stattin P, Soderberg S, Hallmans G, Bylund A, Kaaks R, Stenman UH, Bergh A and Olsson T: Leptin is associated with increased prostate cancer risk: a nested case-referent study. J Clin Endocrinol Metab 86: 1341-1345, 2001.

10. Szenajch J, Kozak A, Pawlak WZ, Anusik J, Doniec J, Micula A, Wisniewski P and Wcislo G: Expression of leptin and its receptor in some human cancers: preliminary results. Wspólcz Onkol 4: 228-233, 2002.

11. Malendowicz LK, Rucinski M, Macchi C, Spinazzi R, Ziolkowska A, Nussdorfer GG and Kwias Z: Leptin and leptin receptors in the prostate and seminal vesicles of the adult rat. Int J Mol Med 18: 615-618, 2006

12. Price D: Comparative aspects of development and structure in the prostate. Natl Cancer Inst Monogr 12: 1-27, 1963.

13. Banerjee PP, Banerjee S, Tilly KI, Tilly JL, Brown TR and Zirkin BR: Lobe-specific apoptotic cell death in rat prostate after androgen ablation by castration. Endocrinology 136: 4368-4376, 1995.

14. Prins GS and Woodham C: Autologous regulation of androgen receptor messenger ribonucleic acid in the separate lobes of the rat prostate gland. Biol Reprod 53: 609-619, 1995.

15. Terry DE and Clark AF: Glycosaminoglycans in the three lobes of the rat prostate following castration and testosterone treatment. Biochem Cell Biol 74: 653-658, 1996.

16. Pu Y, Huang L and Prins GS: Sonic hedgehog-patched Gil signaling in the developing rat prostate gland: lobe-specific suppression by neonatal estrogens reduces ductal growth and branching. Dev Biol 273: 257-275, 2004.

17. Pestov NB, Korneenko TV, Adams G, Tillekeratne M, Shakhparonov MI and Modyanov NN: Nongastric H/K-ATPase in rodent prostate: lobe-specific expression and apical localization. Am J Physiol 282: C907-C917, 2002.

18. Takahashi W, Afiatpour P Jr, Foster HE, Ikeda K, Wada Y, Weiss RM and Latifpour J: The effect of castration on endothelins, their receptors and endothelin converting enzyme in rat prostate. Naunyn Schmiedebergs Arch Pharmacol 366: 166-176, 2002.

19. Kwong J, Chan FL, Jiang S, Guo Y, Imasato Y, Sakai H, Koropatnick J, Chin JL and Xuan JW: Differential expression of PSP94 in rat prostate lobes as demonstrated by an antibody against recombinant GST-PSP94. J Cell Biochem 74: 406-417, 1999.

20. Wilson MJ, Casey C, Woodson M and Sinha AA: Reverse zymography studies of protease inhibitors in the secretions of different lobes of rat prostate. Arch Androl 42: 109-118, 1999.

21. Scolnik M, Tykochinsky G, Servadio C and Abramovici A: The development of vascular supply of normal rat prostate during the sexual maturation: an angiographic study. Prostate 21: 1-14, 1992.

22. Albertin G, Carraro G, Petrelli L, Guidolin D, Neri G and Nussdorfer GG: Endothelin-1 and adrenomedullin enhance the growth of human adrenocortical carcinoma-derived SW-13 cell line by stimulating proliferation and inhibiting apoptosis. Int $\mathbf{J}$ Mol Med 15: 469-474, 2005. 
23. Markowska A, Belloni AS, Rucinski M, Parenti AR, Nardelli GB, Drews K, Nussdorfer GG and Malendowicz LK: Leptin and leptin receptor expression in the myometrium and uterine myomas: is leptin involved in tumor development? Int J Oncol 27: 1505-1509, 2005.

24. Rucinski M, Albertin G, Spinazzi R, Ziolkowska A Nussdorfer GG and Malendowicz LK: Cerebellin in the rat adrenal gland: gene expression and effects of CER and [desSer ${ }^{1}$ CER on the secretion and growth of cultured adrenocortical cells. Int J Mol Med 15: 411-415, 2005.

25. Spinazzi R, Ziolkowska A, Neri G, Nowak M, Rebuffat P, Nussdorfer GG, Andreis PG and Malendowicz LK: Orexins modulate the growth of cultured rat adrenocortical cell, acting through type 1 and type 2 receptors coupled to the MAPK p42/ p44- and p38-dependent cascades. Int J Mol Med 15: 847-852, 2005.

26. Albertin G, Carraro G and Nussdorfer GG: Human adrenomedullin gene silencing by short interfering RNAs: a preliminary study. Int J Mol Med 15: 579-583, 2005.

27. Rucinski M, Andreis PG, Ziolkowska A, Nussdorfer GG and Malendowicz LK: Differential expression and function of beacon in the rat adrenal cortex and medulla. Int J Mol Med 16: 35-40, 2005.

28. Ghilardi N, Ziegler S, Wiestner A, Stoffel R, Heim MH and Skoda RC: Defective STAT signaling by the leptin receptor in diabetic mice. Proc Natl Acad Sci 93: 6231-6235, 1996.

29. Bjorbaek C, Uotani S, Da Silva B and Flier JS: Divergent signaling capacities of the long and short isoforms of the leptin receptor. J Biol Chem 272: 32686-32695, 1997.
30. Murakami T, Yamashita T, Iida M, Kuwajima M and Shima K A short form of leptin receptor performs signal transduction. Biochem Biophys Res Commun 231: 26-29, 1997.

31. Tartaglia LA: The leptin receptor. J Biol Chem 272: 6093-6096, 1997.

32. Yamashita T, Murakami T, Otani S, Kuwajima M and Shima K: Leptin receptor signal transduction: OBRa and OBRb of fa type. Biochem Biophys Res Commun 246: 752-759, 1998.

33. Ahima RS, Saper CB, Flier JS and Elmqvist JK: Leptin regulation of neuroendocrine system. Front Neuroendocrinol 21: 263-307, 2000

34. Sweeney G: Leptin signaling. Cell Signal 14: 655-663, 2002.

35. Ahima RS and Osei SY: Leptin signaling. Physiol Behav 81: 223-241, 2004.

36. Myers MG Jr: Leptin receptor signaling and the regulation of mammalian physiology. Recent Prog Horm Res 59: 287-304, 2004.

37. Iwasa M, Yokoi $\mathrm{T}$ and Sagisaka K: Binding sites of seminal acid phosphatase to Canavalia gladiata DC lectin. Tohoku J Exp Med 140: 435-441, 1983.

38. Maier G and Fiebig HH: Absence of tumor growth stimulation in a panel of 16 human tumor cell lines by mistletoe extracts in vitro. Anticancer Drugs 13: 373-379, 2002.

39. Camina JP, Lage M, Menendez C, Grana M, Garcia-Devesa J, Dieguez $\mathrm{C}$ and Casanueva FF: Evidence of free leptin in human seminal plasma. Endocrine 17: 169-174, 2002. 